\title{
The effect of using fermented lime (Citrus aurantifolia) waste powder (FLWP) on performance, lymphoid organs, and heterophil/lymphocyte ratio of broiler chickens
}

\author{
Hanna Dzawish Shihah *, Dwi Sunarti, Sri Sumarsih \\ Department of Animal Science, Faculty of Animal and Agricultural Sciences, Diponegoro University, \\ Semarang, 50275 \\ *Correspondence: hannashihah@gmail.com
}

Received: May $4^{\text {th }}, 2021$; Accepted: August 30 ${ }^{\text {th }}, 2021$; Published online: November $17^{\text {th }}, 2021$

Abstrak

Tujuan: Limbah jeruk nipis fermentasi berpotensi sebagai salah satu feed additive yang bermanfaat bagi unggas. Kandungan zat bioaktif seperti asam sitrat yang berada dalam limbah jeruk nipis fermentasi dapat meningkatan performa dan ketahanan tubuh ayam broiler. Penelitian ini bertujuan mengevaluasi efek penggunaan tepung limbah jeruk nipis (Citrus aurantifolia) fermentasi terhadap performa dan ketahanan tubuh ayam broiler.

Metode: Sebanyak 200 ekor ayam broiler betina strain Lohman MB 202 digunakan sebagai materi penelitian. Penelitian dirancang dengan Rancangan Acak Lengkap berupa 4 level penggunaan tepung limbah jeruk nipis fermentasi (TLJNF) yaitu $0 \%, 1 \%, 2 \%$ dan $3 \%$ dalam ransum dengan pengulangan sebanyak 5 kali. Pengukuran parameter penelitian meliputi konsumsi pakan, feed conversion ratio (FCR), bobot akhir, persentase karkas, persentase lemak abdominal, bobot relatif organ limfoid (timus, limpa, dan Bursa fabricius), dan rasio heterofil/limfosit (H/L ratio) ayam broiler. Pengolahan data menggunakan analisis ragam dan apabila terdapat pengaruh nyata antar perlakuan maka dilanjutkan uji beda Duncan. Data diolah dengan bantuan program SPSS 19.0.

Hasil: Penggunaan tepung limbah jeruk nipis fermentasi (TLJNF) secara nyata $(p<0,05)$ dapat meningkatkan bobot relatif Bursa fabricius secara berurutan T0 0,11\%; T1 0,19\%; T2 0,19\%; dan T3 $0,17 \%$. Penggunaan TLJNF pada level $3 \%$ nyata $(p<0,05)$ meningkatkan rasio $H / L$ ayam broiler. Hasil data performa, persentase karkas dan persentase lemak abdominal tidak menampakkan perbedaan nyata $(\mathrm{p}>0,05)$ diantara perlakuan yang diberikan.

Kesimpulan: Penggunaan tepung limbah jeruk nipis fermentasi taraf $1 \%$ dapat meningkatkan bobot relatif Bursa fabricius (0,17-0,19\%) tanpa menurunkan performa ayam broiler.

Kata Kunci: asam sitrat; Aspergillus niger; broiler; limbah jeruk nipis; performa; ketahanan tubuh

Abstract

Objective: Fermented lime waste had potential value as a feed additive for poultry. A Bioactive compound such as citric acid in the lime waste can improve the broiler's performance and body 
resistance. The study purposed to evaluate the effect of using fermented lime waste powder (FLWP) on the broiler performance and body resistance.

Methods: This study used 200 female broiler strain Lohman MB 202 chickens. The research design used a completely randomized design with four treatment levels of fermented lime waste powder (FLWP) by $0 \%, 1 \%, 2 \%$, and $3 \%$ in every rations with each treatment replicated five times. The parameters observed are feed intake, feed conversion ratio, final body weight, carcass percentage, abdominal fat percentage, lymphoid organ's relative weight, and heterophil/lymphocyte ratio $(\mathrm{H} / \mathrm{L}$ ratio). Data were calculated using the analysis of variance and difference test with Duncan's Multiple Range Test. Data analysis were calculated using the SPSS 19.0 program.

Results: The result indicates that using FLWP improved $(\mathrm{p}<0.05)$ the relative weight of the Bursa of fabricius at T0 0.11\%; T1 0.19\%; T2 0.19\%; and T3 0.17\% respectively. The FLWP at 3\% level improved $(\mathrm{p}<0.05)$ broiler chicken's H/L ratio. Performance, carcass percentage, and abdominal fat percentage among treatments were not influenced ( $p>0.05)$ by FLWP addition.

Conclusions: It concludes that adding FLWP at a $1 \%$ level increases the relative weight of Bursa of fabricius $(0.17-0.19 \%)$ without depressed performance of broiler.

Keywords: Aspergillus niger; body resistance; broiler; citric acid; lime waste; performance

\section{INTRODUCTION}

Based on data of Ministry of Agriculture Republic Indonesia [1], citrus production in Indonesia was 1,800,524 tons/year. Lime (Citrus aurantifolia) has been becoming the one of plants that grow well in Indonesia [2]. Lime (Citrus aurantifolia) wastes such as peels still contain citric acid used as an acidifier for poultry feed. The application of lime waste as a poultry feed additive was constrained by the high content of pectin so that the benefits of citric acid in lime waste could not be optimal. Providing a 3\% pectin ration could decrease performance [3]. One way to degrade pectin fibers is by using the pectinase enzyme to the small component like oligosaccharide pectic. The fermentation process by Aspergillus niger can help to degrade pectin and optimize citric acid in lime waste utilization. Citric acid was added to feed rations that can increase the immune system of broiler chickens. Good gut health stimulated better growth performance for broiler chickens. The body resistance indicator could be observed on the lymphoid organs and $\mathrm{H} / \mathrm{L}$ ratio of broiler chickens. The lymphoid organs like thymus, spleen, and Bursa of fabricius confer protection against pathogen attacks $[4,5]$.

The treatment with $2 \%$ dried sweet orange (Citrus sinensis) peel significantly increased feed intake, and body weight, as well as decreased triglycerides, the relative weight of liver and abdominal fat [6]. On the other hand, research by [7] states that addition of $2.5 \%$ lime can reduce the performance of broiler chickens, so giving more than that level is not recommended. Utilization of lime peel as a feed additive for poultry is hampered by the fruits high in pectin content. Putting 3\% pectin fiber in the ration could reduce performance, digestive tract health and disrupt the balance of ileal microflora [3].

The study objective purposed to evaluate the result using fermented lime waste powder by Aspergillus niger on broiler chicken's performance and body resistance. This study's advantage was to give scientific information about using lime (Citrus aurantifolia) waste powder fermented by Aspergillus niger on the performance and broiler chicken's body resistance. The study's hypothesis was that using fermented lime (Citrus aurantifolia) waste powder could improving the body resistance and performance of broiler chickens.

\section{MATERIALS AND METHODS}

The experiment was conducted in September-December 2020 in Poultry Production Laboratory, Faculty of Animal and Agricultural Sciences, Diponegoro University Semarang. The material used in 
this study were day-old chicks strain Lohman MB 202, BR 1 commercial feed, feed ingredients (corn, rice bran, soybean meal, fish meal, DL-Methionine, L-Lysine, $\mathrm{CaCO}_{3}$, soybean oil, fermented lime waste powder (FLWP), and premix), vaccines, and desinfectans. The research procedure were preparation (ration and house), rearing management, and data collection.

\section{Experimental design}

A total of 200 female broiler day-old chicks strain Lohman MB 202 was reared for 35 days in the opened house. Brooding period (14 days early) is the gold period of the day-old chicks growth. This period is the key factor of rearing management on broiler and cannot be converted to the next phase. BR1 Commercial feeds were given to broiler chickens during 1-14 days old. The treatments were given to broiler chickens at 14 days old with an average body weight of $379.73 \pm 18.72 \mathrm{~g}, \mathrm{CV} 4.93 \%$. It uses fermented lime waste powder treatments in rations at $0 \%, 1 \%, 2 \%$, and $3 \%$ levels following a completely randomized design.

\section{Preparation for fermented lime waste powder}

Lime wastes were cleaned and washed with running water. The lime wastes are then drained and sliced into small pieces with a thickness $\pm 0.5 \mathrm{~mm}$, then dried by air-hydrate for about two days, and ground into powder form. The lime waste powder was sterilized using an autoclave at $121^{\circ} \mathrm{C}$ temperature for 15 minutes and then cooled within room temperature $20-25^{\circ} \mathrm{C}$. The lime waste powder was fermented with Aspergillus niger at 3\% level and added with distilled water until the water content reached $65 \%$, then it fermented aerobically for five days at room temperature. The fermentation results were dried by air-hydrate for 24 hours before given to the chickens.

High Performance Liquid Chromatography (HPLC) method used to analyze citric contents [8]. The result showed that the fermented lime waste citric contents were $0.94 \mathrm{mg} / \mathrm{kg}$. It was higher than nonfermented lime waste, $0.10 \mathrm{mg} / \mathrm{kg}$. Pectin content also was calculated by extraction method [9]. The content of Fermented lime waste pectin was $2.73 \%$ on wet basis $(w b)$. It was lower than that of non-fermented lime waste, $7.80 \%$ on wet basis (wb).

\section{Feed formulation}

Feed formulations were presented in Tables 1 and 2. Those formulations were calculated based on the Indonesian National Standard of Broiler Feeds.

\section{Data collection}

Performance parameters (feed intake, feed conversion ratio (FCR), and body weight) were weighed and calculated weekly. On the $35^{\text {th }}$ day, the blood sample was taken through the brachial vein of broiler chickens by $1 \mathrm{ml}$ using a syringe and inserted blood into an Ethylene Diamine Tetra Acetic Acid (EDTA) tube. Heterophil/lymphocyte ratio (H/L ratio) analysis used the blood smear preparation method [26].

The carcass processing was performed on the $36^{\text {th }}$ day, following the slaughter in which every treatment had one broiler chicken in each replication. Carcass percentage, abdominal fat percentage, lymphoid organs relative weight were determined $[7,10]$ :

$$
\begin{aligned}
\text { Carcass Percentage } & =\frac{\text { Carcass Weight }(\mathrm{g})}{\text { Live Weight }(\mathrm{g})} \times 100 \% \\
\text { Abdominal Fat Percentage } & =\frac{\text { Abdominal Fat Weight }(\mathrm{g})}{\text { Live Weight }(\mathrm{g})} \times 100 \%
\end{aligned}
$$

Lymphoid Organs Relative Weight $=\frac{\text { Lymphoid Organs Weight }(\mathrm{g})}{\text { Live Weight }(\mathrm{g})} \times 100 \%$ 
Table 1. Broiler's Feed Formulation and Nutrient Composition on 15-21 days

\begin{tabular}{|c|c|c|c|c|}
\hline \multirow{2}{*}{ Feed Ingredient } & \multicolumn{4}{|c|}{ FLWP (\%) } \\
\hline & 0 & 1 & 2 & 3 \\
\hline Yellow Corn & 56.40 & 56.40 & 55.40 & 54.40 \\
\hline Soybean Meal & 29.80 & 29.80 & 29.80 & 29.80 \\
\hline Fish Meal & 7.70 & 7.70 & 7.70 & 7.70 \\
\hline Rice Bran & 2.50 & 2.50 & 2.50 & 2.50 \\
\hline FLWP & 0.00 & 1.00 & 2.00 & 3.00 \\
\hline Soybean Oil & 2.00 & 1.00 & 1.00 & 1.00 \\
\hline Premix & 0.50 & 0.50 & 0.50 & 0.50 \\
\hline $\mathrm{CaCO}_{3}$ & 0.50 & 0.50 & 0.50 & 0.50 \\
\hline D-L Methionine & 0.40 & 0.40 & 0.40 & 0.40 \\
\hline$L$ - Lysine & 0.20 & 0.20 & 0.20 & 0.20 \\
\hline Nutrient Composition & & & & \\
\hline Crude Protein $(\%)^{1}$ & 21.00 & 21.10 & 21.20 & 21.20 \\
\hline Crude Fiber $(\%)^{1}$ & 4.49 & 4.71 & 4.90 & 5.09 \\
\hline Ether Extract $(\%)^{1}$ & 3.21 & 3.23 & 3.22 & 3.21 \\
\hline Ash $(\%)^{1}$ & 6.06 & 6.16 & 6.64 & 6.33 \\
\hline Metabolic Energy (Kcal/Kg) & $3,037.87$ & $3,012.20$ & $3,023.02$ & $3,032.83$ \\
\hline
\end{tabular}

${ }^{1}$ Based on the Analysis at the Laboratory of Nutrition and Feed Science Calculation Result, Faculty of Animal and Agricultural Sciences, Diponegoro University, Semarang. ${ }^{2} \mathrm{ME}$ (metabolizable energy) was predicted based on Bolton formulation [30] as follow: $40.81\{0.87$ [CP +2.25 crude fat + nitrogen-free extract] +2.5$\}$. FLWP $=$ Fermented Lime Waste Powder

Table 2. Broiler's Feed Formulation and Nutrient Composition on 22-35 days

\begin{tabular}{|c|c|c|c|c|}
\hline \multirow{2}{*}{ Feed Ingredients } & \multicolumn{4}{|c|}{ FLWP (\%) } \\
\hline & 0 & 1 & 2 & 3 \\
\hline Yellow Corn & 59.40 & 58.40 & 57.90 & 57.20 \\
\hline Soybean Meal & 28.50 & 28.20 & 28.00 & 28.00 \\
\hline Fish Meal & 6.40 & 6.60 & 6.60 & 6.50 \\
\hline Rice Bran & 1.70 & 1.90 & 1.90 & 1.90 \\
\hline FLWP & 0.00 & 1.00 & 2.00 & 3.00 \\
\hline Soybean Oil & 3.00 & 2.90 & 2.60 & 2.40 \\
\hline Premix & 0.20 & 0.20 & 0.20 & 0.20 \\
\hline $\mathrm{CaCO}_{3}$ & 0.20 & 0.20 & 0.20 & 0.20 \\
\hline D-L Methionine & 0.40 & 0.40 & 0.40 & 0.40 \\
\hline$L$ - Lysine & 0.20 & 0.20 & 0.20 & 0.20 \\
\hline \multicolumn{5}{|l|}{ Nutrient Composition } \\
\hline Crude Protein $(\%)^{1}$ & 20.00 & 20.10 & 20.10 & 20.20 \\
\hline Crude Fiber $(\%)^{1}$ & 4.29 & 4.50 & 4.70 & 4.89 \\
\hline Ether Extract $(\%)^{1}$ & 3.02 & 3.05 & 3.05 & 3.03 \\
\hline $\operatorname{Ash}(\%)^{1}$ & 5.04 & 5.17 & 5.24 & 5.31 \\
\hline Metabolic Energy $(\mathrm{Kcal} / \mathrm{Kg})^{2}$ & $3,102.30$ & $3,108.28$ & $3,108.26$ & $3,111.76$ \\
\hline
\end{tabular}

${ }^{1}$ Based on the Analysis at the Laboratory of Nutrition and Feed Science Calculation Result, Faculty of Animal and Agricultural Sciences, Diponegoro University, Semarang. ${ }^{2} \mathrm{ME}$ (metabolizable energy) was predicted based on Bolton formulation [30] as follow: $40.81\{0.87$ [CP +2.25 crude fat + nitrogen-free extract] +2.5$\}$. FLWP = Fermented Lime Waste Powder

\section{Statistical analysis}

Data were analyzed using the analysis of variance (ANOVA) in the SPPS 19.0 program. The result was also presented at the standard error of the mean (SEM). If there are significant differences among treatment groups, it was carried out by Duncan's Multiple Range Test (DMRT) analysis. 


\section{RESULTS}

\section{Performance of Broiler Chickens}

Performance of broiler chickens fed fermented lime waste powder was presented in the following Table 3. The statistical analysis results show that adding fermented lime waste powder feed at various levels did not affect the broiler chicken's performance: final body weight, feed intake, and feed conversion ratio $(p>0.05)$.

\section{Carcass and Abdominal Fat Variable of Broiler Chickens}

Carcass percentage and abdominal fat percentage of broiler chickens were presented in Table 4. The statistical analysis results show that fermented lime waste powder did not influence the carcass percentage and abdominal fat percentage in broiler chickens $(\mathrm{p}>0.05)$ (Table 4).

\section{Lymphoid Organ's relative weight and H/L ratio of Broiler Chickens}

Broiler chicken's lymphoid organ relative weight and $\mathrm{H} / \mathrm{L}$ ratio data were presented in the following Table 5. The results show that feeding fermented lime waste powder did not affect the thymus and spleen $(p>0.05)$ but increased the Bursa of fabricius's relative weight $(p<0.05)$. Based on Table 5, the Heterophil/lymphocyte ratio was greater $(\mathrm{p}<0.05)$ in the addition at $3 \%$ fermented lime waste compared to other treatments.

\section{DISCUSSIONS}

The statistical analysis results show that adding fermented lime waste powder feed at various levels did not influence the broiler chicken's performance: final body weight, feed intake, and feed conversion ratio $(p>0.05)$. In contrast with the previous study, the research showed that the using of orange (Citrus sinensis) peels powder in the rations decreased broiler performance [11]. It evidenced that fermentation process treatment using lime waste powder did not negatively impact the broiler's performance.

The nutrient content (Table 1 and 2) of each treatment was relatively similar, so as it causes broiler chickens to feed consumption among treatments also the same. The similar broiler feed intake among treatment resulting

Table 3. Performance of broiler chickens fed fermented lime waste powder (FLWP)

\begin{tabular}{|c|c|c|c|c|c|c|}
\hline \multirow{2}{*}{ Items } & \multicolumn{4}{|c|}{ FLWP (\%) } & \multirow{2}{*}{ SEM } & \multirow{2}{*}{$\mathrm{p}$ Value } \\
\hline & 0 & 1 & 2 & 3 & & \\
\hline Cumulative Feed Intake (g/bird) & $1,983.14$ & $1,934.20$ & $1,887.03$ & $1,956.08$ & 26.46 & 0.64 \\
\hline FCR & 2.18 & 2.05 & 2.14 & 2.16 & 0.04 & 0.65 \\
\hline Final Body Weight (g/bird) & $1,289.82$ & $1,329.48$ & $1,262.27$ & $1,268.53$ & 11.93 & 0.18 \\
\hline
\end{tabular}

Table 4. Carcass percentage and abdominal fat percentage of broiler chickens fed FLWP

\begin{tabular}{|c|c|c|c|c|c|c|}
\hline \multirow{2}{*}{ Items } & \multicolumn{4}{|c|}{ FLWP (\%) } & \multirow{2}{*}{ SEM } & \multirow{2}{*}{$p$ Value } \\
\hline & 0 & 1 & 2 & 3 & & \\
\hline Carcass percentage (\%) & 67.8 & 67.3 & 65.3 & 66.5 & 0.37 & 0.12 \\
\hline Abdominal Fat Percentage (\%) & 0.98 & 1.17 & 1.24 & 0.93 & 0.08 & 0.57 \\
\hline
\end{tabular}

SEM $=$ Standard Error of Mean; FLWP $=$ Fermented Lime Waste Powder

Table 5. Lymphoid organ's relative weight and H/L ratio of broilers fed FLWP

\begin{tabular}{|c|c|c|c|c|c|c|}
\hline \multirow{2}{*}{ Items } & \multicolumn{4}{|c|}{ FLWP (\%) } & \multirow{2}{*}{ SEM } & \multirow{2}{*}{$\mathrm{p}$ Value } \\
\hline & 0 & 1 & 2 & 3 & & \\
\hline Thymus (\% Live Weight) & 0.23 & 0.22 & 0.22 & 0.22 & 0.01 & 1.00 \\
\hline Spleen (\%Live Weight) & 0.10 & 0.10 & 0.10 & 0.11 & $<0.01$ & 0.85 \\
\hline Bursa of fabricius (\%Live Weight) & $0.11^{\mathrm{b}}$ & $0.19^{a}$ & $0.19^{\mathrm{a}}$ & $0.17^{\mathrm{a}}$ & 0.01 & $<0.01$ \\
\hline Heterophil/Lymphocyte (H/L) Ratio & $0.40^{\mathrm{b}}$ & $0.41^{\mathrm{b}}$ & $0.47^{\mathrm{b}}$ & $0.75^{\mathrm{a}}$ & 0.05 & $<0.01$ \\
\hline
\end{tabular}


broiler chicken's performance also did not different $(\mathrm{p}>0.05)$. Nutrient content such as metabolic energy content in the ration affects broiler chicken's consumption [12]. Feed consumption will increase if the rations' metabolic energy and crude protein ratio are low.

The fermented lime waste powder did not influence the carcass percentage and abdominal fat percentage in broiler chickens $(p>0.05)$. Those results were resemble previous study that feeding dietary graded levels of dried lemon did not affect broiler chicken's carcass percentage and abdominals fat [7]. The citric acid in fermented lime waste powder has not yet reduced broiler chicken's abdominal percentage. An additional organic acids at $0.02-0.06 \%$ level did not affect abdominal fat percentage [13].

Broiler chicken's carcass and abdominal fat percentage still in the normal range, it conforms to study result that broiler chickens carcass percentage at the range $65.3-67.0 \%$ [14], while it generates broiler chicken abdominal fat percentage at the standard range, that is, $0.96 \%$ [15]. Moreover, it was reported that broiler chicken abdominal fat percentage reaches range at $1.33-1.70 \%$ [16].

The increasing Bursa of fabricius indicates that broiler chicken's body resistance also increased. The Bursa of fabricius was a predominant lymphoid organ in broiler that responding diseases attack or stressful condition. The citric acid nutrient in fermented lime waste helps Bursa of fabricius did not work excessively to maintain the broiler chicken's body resistance. The results were similar to the previous study that offering $0.8 \%$ citric acid increased the Bursa of fabricius's relative weight. One of the mucosal immune system is found in the digestive tract of the body.

Citric acid-activated immune cells on the intestinal mucosa surface so that Bursa of fabricius's function in producing B cells was not excessive, and the Bursa of fabricius atrophy process did not occur quickly [5]. The mucosal surface of the digestive tract is susceptible to infection, so most infectious agents attack the body through the digestive tract. The intestine becomes the entrance for various foreign antigens that enter through food. The immune system in the intestinal mucosa plays a role in detecting and killing pathogenic organisms. The structure of the intestinal mucosa is thin and permeable due to its physiological activity, so it needs to be protected from pathogenic infections. Organic acids like citric acid make acidic conditions that inhibit the colonization of pathogenic bacteria on the intestinal wall and reduce the production of toxic bacteria thus preventing the damage to intestinal epithelial cells [17].

The Bursa of fabricius undergoes an atrophic process depending on age and varies greatly in time [18]. The presence of infection caused the atrophy process occuring quickly. When an infection occured, the cells in the Bursa of fabricius follicles will reduce. Follicles decay started from the medulla, then continued in the cortex to the whole and caused the loss of Bursa of fabricius follicles [19]. When the chickens have a disease, Bursa of fabricius produces more often antibodies thus it may cause the depletion of lymphoid follicles that in turn down the relative weight of Bursa of fabricius. The more often releasing glucocorticoid may cause atrophy of the Bursa of fabricius [20].

The Bursa of fabricius was an organ responsible for developing B lymphocytes that produced antibodies [21]. Citric acid supplementation improved the immune status of broiler chickens as indicated by the higher density of immunocompetent cells in the medullary Bursa follicular. Dense immunocompetent cells indicated the healthy condition of chickens. They have higher immune to attack pathogens and disease [22].

In this study, the relative weights of thymus and spleen organ showed the same results $(p>0.05)$ (Table 5). Previous study showed that addition at $1 \%$ citric acid did not affect the relative weight of spleen and thymus [23], while supplementation citric acid at $2 \%$ improved the relative organ of thymus and spleen [24].

The thymus was one of the main organs responsible for producing $\mathrm{T}$ lymphocytes as antibodies, while the spleen was a secondary lymphoid organ that contributes to support the body's defense process from infectious agents. The spleen serves as an immunological response. Spleen will filter out foreign 
substances that enter in the blood [20]. The thymus and spleen organ's relative weight was in normal conditions indicating broilers were in good health. Infection affects the shrinkage of lymphocyte cell's thymus and spleen organs [21].

The addition of citric acid $0.5 \%$ helps improve broiler's immunity. The density of the lymphocytes was larger in the lymphoid organs and tissues of the citric acid supplementation. The higher density of lymphocytes suggests that the birds treated with CA possessed stronger immune status to fight pathogens [25].

The result of heterophil/lymphocyte are T0 0.40; T1 0.41; T2 0.47 respectively; and T3 0.75. Citric acid in the FLWP help decreasing pathogenic bacteria in the gastrointestinal tract. Citric acid can be used to minimize variation in the lower intestinal tract environment. Decreasing intestinal pathogen challenges improved the gut health, availability of nutrients and energy for growth and also immune responses of birds. Chickens that are in a healthy and comfortable condition will reduce the stress level of chickens due to pathogenic bacteria attack [4]. Stress level indicators of birds can be identified from the value of $\mathrm{H} / \mathrm{L}$ ratio.

Heterophil/ lymphocyte ratio (H/L ratio) was part of white blood which maintained body resistance. The high or low $\mathrm{H} / \mathrm{L}$ ratio indicated that broiler chickens were not confident, e.g., under stress conditions and pathogen attack. Decreasing or increasing the leukocyte level in the blood is a physiological and pathological response in the body of poultry. Lymphocytes are the most dominant part of the white blood cells. Heterophil acted as the first antibody keeping from pathogen infection [26]. The lower lymphocyte indicated decreasing white blood in the body [5].

The $\mathrm{H} / \mathrm{L}$ ratio value of various treatments was still classified as usual. The heterophil/ lymphocyte ratio was low if the value is 0.2 and high at 0.8 [27]. Heterophil/lymphocyte ratio was related to the performance of the lymphoid organs, especially the spleen. The spleen was responsible for binding blood antigens and lymphocytes, so higher bound size affected the spleen's increasing size [5].
The increase in the $\mathrm{H} / \mathrm{L}$ ratio was thought to respond to the presence of citric acid fermented lime waste powder (FLWP). Supplementation of high citric acid caused acid stress, furthermore the shrinkage of the Bursa of fabricius and enlargement of the spleen [28]. Nevertheless, the result of this study did not affect extremely lymphoid organs size's change. Previous research shows that supplementation of dried lemon as much as $4.5 \%$ increased the $\mathrm{H} / \mathrm{L}$ ratio of broiler chickens [29].

\section{CONCLUSIONS}

The addition of FLWP at a $1 \%$ level increases the relative weight of Bursa of fabricius $(0.17 \%-0.19 \%)$ without depressed the broiler's performance.

\section{CONFLICT OF INTEREST}

The authors state no conflicts of interest with other people or institution concerning the subtansial major discussed in this paper.

\section{ACKNOWLEDGMENTS}

We would like to thanks to LPDP scholarship from the Ministry of Finance of the Republic of Indonesia, which has fully funded this research.

\section{REFERENCES}

1. Kementerian Pertanian. 2016. Outlook Komoditas Pertanian Subsektor Hortikultura Jeruk. ISSN: 1907-1507. Pusat Data dan Sistem Informasi Pertanian, Kementerian Pertanin, Jakarta.

2. Prastiwi, S. S. dan F. F. Sofian. 2017. Kandungan dan aktivitas farmakologi jeruk nipis (Citrus aurantifolia Swing). Jurnal Farmaka. 15(2):1-8.

3. Kermanshahi, H., M. D. Shakouri, and A. Daneshmand. 2018. Effects of nonstarch polysaccharides in semi-purified diets on performance, serum metabolites, gastrointestinal morphology, and microbial population of male broiler chickens. Livest. Sci. 214:93-97. Doi: 10.1016/j.livsci.2018.04.012 
4. Islam, K. M. S. 2012. Use of citric acid in broiler diets. Worlds Poult. Sci. J. 68(1):104118. Doi: $10.1017 / S 0043933912000116$

5. Jamilah, N. Suthama, and L. D. Mahfudz. 2013. Production performance and immune responses of broilers given single step down diet with the inclusion of citric acid as an acidifier. Indonesian Journal of Animal and Veterinary Sciences. 18(4):251257. Doi: 10.14334/jitv.v18i4.331

6. Abbasi, H., A. Seidavi, W. Liu, and L. Asadpour. 2015. Investigation on the effect of different levels of dried sweet orange (Citrus sinensis) pulp on performance, carcass characteristics and physiological and biochemical parameters in broiler chicken. Saudi J. Biol. Sci. 22(2):139-146. Doi: 10.1016/j.sjbs.2014.09.006

7. Basir, R., and M. Toghyani. 2017. Effect of dietary graded levels of dried lemon (Citrus aurantifolia) pulp on performance, intestinal morphology, and humoral immunity in broiler chickens. Int. J. Recycl. Org. Waste Agricult. 6(2):125-132. Doi: 10.1007/s40093-017-0159-5

8. Magdziak, Z., M. Mleczek, P. Rutkowski, and P. Goliński. 2017. Diversity of low-molecular weight organic acids synthesized by Salix growing in soils characterized by different $\mathrm{Cu}, \mathrm{Pb}$ and Zn concentrations. Acta. Physiol. Plant. 39(137):1-15. Doi: 10.1007/s11738-017-24 34-5

9. Lazim, A. M., F. Mokhtar, S. F. M. Yusof, I. Ahmad, and A. Hakam. 2013. Synthesis and characterization of $\mathrm{pH}$ sensitive hydrogel using extracted pectin from dragon fruit peel. Malays. J. Anal. Sci. 17(3):481-489.

10. Pertiwi D. D, R. Murwani, and T. Yudiarti. 2017 Bobot relatif saluran pencernaan ayam broiler yang diberi tambahan air rebusan kunyit dalam air minum. Jurnal Peternakan Indonesia. 19(2):61-65. Doi: 10.25077/jpi.19.2.60-64.2017

11. Oluremi, O. I. A., P. M. Mou, and A. Y. Adenkola. 2008. Effect of fermentation of sweet orange (Citrus sinensis) fruit peel on its maize replacement value in broiler diet. Livest. Res. Rural. Dev. 20(2).

12. Haroen U, A. Budiansyah, N. Noperdiman, H. Harnita, and J. Jusalia. 2019.
Performance of broiler chickens fed diet added with buffaloes rumen fluid enzymes from slaughterhouses. Bull. Animal Science. 43(2):109-117. Doi: 10.21059/buletinpeternak.v43i2.41880

13. Nguyen, D. H., K. Y. Lee, M. Mohammadigheisar, and I. H. Kim. 2018 Evaluation of the blend of organic acids and medium-chain fatty acids in matrix coating as antibiotic growth promoter alternative on growth performance, nutrient digestibility, blood profiles, excreta microflora, and carcass quality in broilers. Poult. Sci. 97(12):4351-4358. Doi: 10.3382/ps/pey339

14. Muharlien M, E. Sudjarwo, D. L. Yulianti, A. A. Hamiyanti, and H. S. Prayogi. 2020 Comparative production performance of broiler under the opened house and closed house system. Indonesian Journal of Animal Science. 30(1):86-91. Doi: 10.21776/ ub.jiip.2020.030.01.09

15. Nikolova, N., Z. Pavlovski Z, N. Milošević, and L. Peric. 2007. The quantity of abdominal fat in broiler chicken of different genotypes from fifth to the seventh week of age. Biotechnol. Anim. Husb. 23(5):331-338. Doi: 10.2298/BAH07 $02331 \mathrm{~N}$

16. Potença, A, A. E. Murakami, J. I. M. Fernandes, M. Matsushita and E. L. Nakagawa 2008. Performance, abdominal fat deposition and bone characteristics of broilers fed diets. Rev. Bras. Cienc. Avic. 10(4):239-244. Doi: 10.1590/S1516635X2008000400008

17. Khan, S. H., and J. Iqbal. 2016. Recent advances in the role of organic acids in poultry nutrition. J. Appl. Anim. Res. 44(1):359-369. Doi: 10.1080/09712119.2015. 1079527

18. Ayman, U., Md. R. Alam, and S. K. Das. 2020. Age-related development and histomorphological observations of bursa of Fabricius in sonali chicken. J. Adv. Biotechnol. Exp. Ther. 3(1):20-28. Doi: 10.5455/jabet.2020.d10

19. Rohyati, E. 2012. Gambaran mikroskopis nekrosa sel dan deplesi folikel limfoid Bursa fabricius ayam broiler pasca pemberian probiotik B-mix dan infeksi Salmonella enteritidis. Buletin Pertanian 
Terapan. 19(1):83-91.

20. Salam, S., D. Sunarti, and I. Isroli. 2013. Physiological responses of blood and immune organs of broiler chicken fed dietary black cumin powder (Nigella sativa) during dry seasons. J. Indones. Trop. Anim. Agric. 38(3):185-191. Doi: 10.14710/jitaa.38.3.185-191

21. Latif, I. K., H. M. Majed, and Saharv. 2014. Determine the weight of thymus, Bursa of fabricius and spleen and its ratio to body weight in some broilers' diseases. Mir. Res. in Vet. Sci. and Anim. 3(1):8-14.

22. Chowdhury, R., K. M. S. Islam, M. J. Khan, M. R. Karim, M. N. Haque, M. Khatun, and G. M. Pesti. 2009. Effect of citric acid, avilamycin, and their combination on the performance, tibia ash, and immune status of broilers. Poult. Sci. J. 88(8):1616-22. Doi: https://doi.org/10.3382/ps.2009-00119

23. Mohammadbagheri, N., and Najafi, R. 2014. Study the effect of citric acid and phytase supplementation on performance, blood lipid, immune system and some carcass characteristics of broiler chickens. Iran. J. Appl. Anim. Sci. 6(2):131-139.

24. Ghazalah, A.A., A. M. Atta, K. Elkloub, M. E. L. Moustafa, and R. F. H. Shata. 2011. Effect of dietary supplementation of organic acids on performance, nutrients digestibility and health of broiler chicks. Int. J. Poult. Sci. 10(3):176-184. Doi: 10.3923/ijps.2011.176.184

25. Haque, M. N., K. M. S. Islam, M. A. Akbar, R. Chowdhury, M. Khatun, M. R. Karim, and B. W. Kemppainen. 2010.
Effect of dietary citric acid, flavomycin and their combination on the performance, tibia ash and immune status of broiler. Can. J. Anim. Sci. 90(1):57-62. Doi: 10.4141/CJAS09048

26. Olivia, B. C., Isroli, dan L. D. Mahfudz, 2017. Jumlah leukosit dan diferensial leukosit dalam darah ayam broiler yang diberi aditif tepung jahe (Zingiber officinale R.) dalam ransum. Jurnal Pengembangan Penyuluhan Pertanian. 14(25):59-64. Doi: 10.36626/jppp.v14i25.48

27. Ferrante, V., C. Mugnai, L. Ferrari, S. P. Marelli, E. Spagnoli, and S. Lolli. 2016. Stress and reactivity in three Italian chicken breeds. Ital. J. Anim. Sci. 15(2):303-309. Doi: 10.1080/1828051X.2016.1185978

28. Nourmohammadi, R., and H. Khosravinia. 2015. Acidic stress caused by dietary administration of citric acid in broiler chickens. Arch. Anim. Breed. 58(2):309-315. Doi: 10.5194/aab-58-309-2015

29. Nobakht, A. 2013. Effects of different levels of dried lemon (Citrus aurantifulia) pulp on performance, carcass traits, blood biochemical, and immunity parameters of broilers. Iran. J. Appl. Anim. Sci. 3(1):145151.

30. Sugiharto, S. T. Yudiarti, I. Isroli, E. Widiastuti, and F. D. Putra. 2017. Effects of feeding cassava pulp fermented with Acremonium charticola on growth performance, nutrient digestibility and meat quality of broiler chicks. S. Afr. J. Anim. Sci. 47(2):130-138. Doi: 10.4314/sajas. v47i2.4 